University of Nebraska - Lincoln

DigitalCommons@University of Nebraska - Lincoln

Biological Systems Engineering: Papers and

Publications

Biological Systems Engineering

1997

\title{
Cast Films from Soy Protein Isolates and Fractions
}

\author{
L. A. Kunte \\ University of Nebraska-Lincoln
}

A. Gennadios

University of Nebraska-Lincoln, aris.gennadios@catalent.com

S. L. Cuppett

University of Nebraska-Lincoln, scuppett1@unl.edu

M. A. Hanna

University of Nebraska-Lincoln, mhanna1@unl.edu

Curtis L. Weller

University of Nebraska-Lincoln, cweller1@unl.edu

Follow this and additional works at: https://digitalcommons.unl.edu/biosysengfacpub

Part of the Biological Engineering Commons

Kunte, L. A.; Gennadios, A.; Cuppett, S. L.; Hanna, M. A.; and Weller, Curtis L., "Cast Films from Soy Protein Isolates and Fractions" (1997). Biological Systems Engineering: Papers and Publications. 104.

https://digitalcommons.unl.edu/biosysengfacpub/104

This Article is brought to you for free and open access by the Biological Systems Engineering at DigitalCommons@University of Nebraska - Lincoln. It has been accepted for inclusion in Biological Systems Engineering: Papers and Publications by an authorized administrator of DigitalCommons@University of Nebraska Lincoln. 


\title{
Cast Films from Soy Protein Isolates and Fractions ${ }^{1}$
}

\author{
L. A. KUnTE, ${ }^{2}$ A. GENNAdiOs, ${ }^{3}$ S. L. CUPPETT, ${ }^{2,4}$ M. A. HANNA, ${ }^{3}$ and C. L. WELLER ${ }^{3}$
}

\begin{abstract}
Cereal Chem. 74(2):115-118

Glycerol-plasticized soy protein films were cast from alkaline aqueous film-forming solutions of laboratory-prepared $7 \mathrm{~S}, 11 \mathrm{~S}$, and soy isolate (LSI) fractions and from commercial soy isolate (CSI). Tensile strength (TS), elongation at break (E), water vapor permeability (WVP), total soluble matter (TSM), protein solubility (PS), and Hunter $L, a$, and $b$ color values of these films were determined. The $11 \mathrm{~S}$ films had greater

TS than 7S films $(P<0.05)$, while LSI films had greater TS than CSI films $(P<0.05)$. No significant differences were detected among mean $\mathrm{E}$ values and among mean WVP values of all films $(P>0.05)$. The 7S films had higher TSM and PS values than 11 S films $(P<0.05)$. CSI films were significantly darker (lower $L$ value) and more yellow (greater positive $b$ value) than LSI films $(P<0.05)$.
\end{abstract}

Edible films and coatings can prolong the shelf life of foods due to their selective barrier properties against movement of moisture, gases, and vapor. Interest in edible packaging is likely to grow in the near future as it has potential for reducing the use of nonedible or synthetic packaging (Gennadios et al 1993a). Kester and Fennema (1986) discussed edible films derived from several polysaccharides, lipids, and proteins. Formation and properties of films from proteins such as casein, whey protein, corn zein, wheat gluten, and soy protein were reviewed by Gennadios et al (1994a).

The film-forming ability of soy proteins has traditionally been utilized in the Far East for production of soy protein-lipid films called yuba films (Wang 1981). The process of yuba film formation consists of boiling soy milk in shallow pans; collecting the films formed (due to surface dehydration) by means of rods; and hanging the films to air-dry (Gennadios and Weller 1991, Brandenburg et al 1993). Jaynes and Chou (1975) developed a method to prepare soy films by spreading soy protein isolate solutions on Teflon-coated baking pans followed by baking the pans at $100^{\circ} \mathrm{C}$ for $1 \mathrm{hr}$. Deposition and drying of soy protein solutions is a more promising method for commercial-scale film production than the traditional yuba film process, since it allows for more consistency and control during film formation (Gennadios and Weller 1991). Gennadios et al (1993a) described a method to develop homogeneous free-standing edible films from commercial isolated soy protein using glycerol as a plasticizer.

Soybean protein consists of two major globulin fractions, the 7S ( $\beta$-conglycinin) and the $11 \mathrm{~S}$ (glycinin), which make up $\approx 37$ and $31 \%$, respectively, of the total extractable proteins (Gennadios et al 1994a). Thanh and Shibasaki (1976) found that the 7S and 11S fractions constituted 48 and $35 \%$, respectively, of total protein. The $7 \mathrm{~S}$ protein is extensively glycosylated and can assume as many as seven different forms due to combinations of its three peptide subunits a, a', and b (Iwabuchi and Yamauchi 1987). On the other hand, the $11 \mathrm{~S}$ protein does not contain an appreciable amount of carbohydrate, and its subunits differ in charge and molecular weight (Iwabuchi and Yamauchi 1987). These structural differences contribute to variations in the functional properties of 7S and 11S fractions (Romijn et al 1991). For instance, the

\footnotetext{
${ }^{1}$ Journal Series No. 11507, Agricultural Research Division, Institute of Agriculture and Natural Resources, University of Nebraska-Lincoln.

${ }^{2}$ Graduate research assistant and associate professor, respectively, Department of Food Science and Technology, University of Nebraska, Lincoln, NE 68583-0919. ${ }^{3}$ Postdoctoral research associate, professor, and associate professor, respectively, Department of Biological Systems Engineering, University of Nebraska, Lincoln, NE 68583-0726.

${ }^{4}$ Corresponding author. Fax: (402)472-1693.
}

Publication no. C-1997-0201-05R.

(C) 1997 by the American Association of Cereal Chemists, Inc.
$11 \mathrm{~S}$ fraction has a more significant impact on gelation characteristics of soy protein than does the $7 \mathrm{~S}$ fraction (Nakamura et al 1985). Film formation on the surface of heated aqueous solutions of $7 \mathrm{~S}$ and $11 \mathrm{~S}$ soy proteins, similar to the formation of yuba films on the surface of heated soy milk, has been reported (Shirai et al 1974, Okamoto 1978). However, no information can be found in the literature related to cast films from $7 \mathrm{~S}$ and $11 \mathrm{~S}$ soy protein fractions.

The purpose of this study was to compare the tensile strength, elongation at break, water vapor permeability, solubility in water, and color properties of films formed from commercial soy protein isolate to those of films formed from laboratory-prepared crude $7 \mathrm{~S}$, crude $11 \mathrm{~S}$, and soy protein isolate.

\section{MATERIALS AND METHODS}

\section{Reagents}

Defatted, low-heat treated soy flakes were obtained from Archer Daniels Midland Co. (Lincoln, NE). Glycerol was purchased from Fisher Scientific Co. (Pittsburgh, PA). A food grade soy protein isolate (SUPRO 620) was obtained from Protein Technologies International (St. Louis, MO). Sodium hydroxide, hydrochloric acid, 2-mercaptoethanol, Tris-HCl buffer, sodium azide, and bicinchoninic acid (BCA) protein assay kit were purchased from Sigma Chemical (St. Louis, MO). Sodium dodecyl sulfate (SDS), acrylamide-bisacrylamide, ammonium persulphate, tetramethylethylenediamine (TEMED), bromophenol blue, and coomassie brilliant blue R-250, all of electrophoresis grade, were purchased from Fisher Scientific Co. (Pittsburgh, PA). Boric acid and sodium hydroxide required for protein determination by the Kjeldahl method were purchased from Ricca Chemical Co. (Arlington, TX), sulfuric acid was purchased from Baxter (McGraw Park, IL), and the catalyst tablets were purchased from Fisher Scientific Co. (Pittsburgh, PA).

\section{Protein Isolation}

Soy protein isolate was prepared from finely ground, low-heat treated, defatted soy flakes as described by Romijn et al (1991). The soy globulin fractions $7 \mathrm{~S}$ and $11 \mathrm{~S}$ were isolated from the same source (defatted soy flakes) using a simultaneous fractionation method developed by Thanh and Shibasaki (1976). This method was based on the differential solubilities of the two globulin fractions at different $\mathrm{pH}$ values. Pellets of crude $7 \mathrm{~S}$, crude $11 \mathrm{~S}$, and soy protein isolate were redissolved separately in $0.03 M$ Tris- $\mathrm{HCl}$ buffer at $\mathrm{pH} 7.8$ (1:40 protein pellets to buffer ratio) and dialyzed overnight using Spectra/Por molecular porous dialysis tubing with a molecular weight cutoff of 6,000-8,000 Da (Spectrum Medical Industries, Inc., Los Angeles, CA). The dia- 
lyzed protein solutions were frozen and freeze-dried (stoppering tray drier, model 77545, Labconco, Kansas City, MO). Temperature programming for $2,000 \mathrm{~mL}$ of frozen solution was -40 to $0^{\circ} \mathrm{C}$ with a ramp of $0.05^{\circ} \mathrm{C} / \mathrm{min}$ and hold time of $10 \mathrm{hr}$ for each stage. The resultant white, fluffy, and shiny protein powder was stored at $-20^{\circ} \mathrm{C}$ until needed.

\section{Gel Electrophoresis}

Purities of the laboratory-prepared $7 \mathrm{~S}, 11 \mathrm{~S}$, and soy protein isolate were assessed using a SDS-PAGE method described by Hames and Rickwood (1981). Slab gel, discontinuous SDS-PAGE was performed using a Mini-PROTEAN II electrophoresis cell (Bio-Rad Laboratories, Hercules, CA). A 10\% resolving gel solution was prepared by mixing $33.33 \%(\mathrm{v} / \mathrm{v})$ acrylamide-bisacrylamide (30:0.8); $12.5 \%(\mathrm{v} / \mathrm{v}) 1.5 \mathrm{M}$ Tris- $\mathrm{HCl}$ buffer $(\mathrm{pH} 8.8) ; 1 \%$ $(\mathrm{v} / \mathrm{v})$ of $10 \%$ SDS solution; and $4.66 \%(\mathrm{v} / \mathrm{v})$ of $1.5 \%$ ammonium persulphate solution in water. The stacking gel solution was prepared by mixing $12.5 \%$ (v/v) acrylamide-bisacrylamide (30:0.8); $25 \%$ (v/v) $0.5 M$ Tris-HCl buffer (pH 6.8); $1 \%$ (v/v) of 10\% SDS solution; and $5 \%(\mathrm{v} / \mathrm{v})$ of $1.5 \%$ ammonium persulphate. Both gel solutions were polymerized using $0.05 \%$ (v/v) TEMED. Protein samples were prepared by heating $\approx 3 \mathrm{mg}$ of protein in $1 \mathrm{~mL}$ of a solution of $2 \%$ SDS, $5 \%$ 2-mercaptoethanol, $0.002 \%$ bromophenol blue, and $10 \%$ glycerol in $0.625 \mathrm{M}$ Tris- $\mathrm{HCl}$ buffer ( $\mathrm{pH} 6.8$ ). About $10 \mu \mathrm{g}$ of each protein solution was loaded onto the gel. Electrophoresis was performed at constant $200 \mathrm{~V}$ until the dye front reached the bottom. Gels were stained in a solution of $0.1 \%$ (w/v) coomassie brilliant blue R-250 in 50\% methanol and 40\% distilled water and $10 \%$ glacial acetic acid (v/v). Gels were destained using 50\% methanol and $40 \%$ distilled water and $10 \%$ glacial acetic acid (v/v).

\section{Protein Content Determination}

Protein content of oven-dried $\left(130^{\circ} \mathrm{C}\right.$ for $\left.4 \mathrm{hr}\right)$ laboratory-prepared crude $7 \mathrm{~S}, 11 \mathrm{~S}$, and soy protein isolate fractions and commercial soy protein isolate powder were determined in triplicate according to AOAC method 981.10 (AOAC 1990) using a 6.25 nitrogen conversion factor.

\section{Film Preparation}

Film-forming solutions were prepared by stirring commercial soy protein isolate (CSI), laboratory-prepared soy protein isolate (LSI), crude $7 \mathrm{~S}$, or crude $11 \mathrm{~S}$ protein $(5 \%, \mathrm{w} / \mathrm{v})$ and glycerol $(1.5 \%, \mathrm{w} / \mathrm{v})$ in distilled water for $15 \mathrm{~min}$. The $\mathrm{pH}$ values of the solutions were adjusted to $10.0 \pm 0.1$ with $2 N$ sodium hydroxide. Subsequently, the solutions were heated in a water bath (Magni Whirl, Blu M Electric Company, Blue Island, IL) at $85^{\circ} \mathrm{C}$ for 30 min, filtered through cheese cloth (grade 40, Fisher Scientific, Pittsburgh, PA) to remove foam and undissolved impurities and poured $(25 \mathrm{~mL})$ in rectangular areas $(10 \times 18 \mathrm{~cm})$ created with thin plastic strips glued to leveled (to the nearest of $0.01 \mathrm{~mm}$ ) Teflon-coated glass plates. Cast solutions were allowed to dry at room temperature $\left(25^{\circ} \mathrm{C}\right)$ for $\approx 15 \mathrm{hr}$ and were then peeled off the plates.

\section{Thickness Measurement}

Thickness was measured to the nearest $2.54 \mu \mathrm{m}$ using a handheld micrometer (B.C. Ames Co., Waltham, MA). Thickness of individual samples for water vapor permeability measurement were determined by averaging five measurements taken one at the center and four on the perimeter of a $7-\times 7-\mathrm{cm}$ film specimen. For film strips used for tensile testing $(10 \times 2.5 \mathrm{~cm})$, thickness was determined as a mean of five measurements taken along the strips.

\section{Tensile Testing}

All films were conditioned for $48 \mathrm{hr}$ in an environmental chamber at $25^{\circ} \mathrm{C}$ and $50 \%$ rh before testing. Tensile testing was performed with a Universal Testing Instrument (model 5566, Instron
Engineering Corp., Canton, MA) on $10 \times 2.5 \mathrm{~cm}$ rectangular film strips. Initial grip separation was set at $50 \mathrm{~mm}$, while cross-head speed was set at $500 \mathrm{~mm} / \mathrm{min}$. Tensile strength (TS) was calculated by dividing maximum (peak) load developed during the test by initial film specimen cross-sectional area. Percentage elongation at break (E) was calculated by dividing film extension at the moment of rupture with $50 \mathrm{~mm}$ (initial gauge length) and multiplying by 100 .

\section{Total Soluble Matter}

Total soluble matter (TSM) of films was determined using a method described by Gontard et al (1992). Initial dry matter of film pieces $(20 \times 20 \mathrm{~mm})$ was measured by drying in an air-circulating oven at $100^{\circ} \mathrm{C}$ for $24 \mathrm{hr}$. These film pieces were placed in beakers containing $50 \mathrm{~mL}$ of distilled water and traces of sodium azide $(0.02 \%, \mathrm{w} / \mathrm{v})$ to prevent microbial growth and stored at room temperature for $24 \mathrm{hr}$ with occasional gentle stirring. Undissolved dry film matter was determined by taking the film pieces out of the beakers and drying them in an air-circulating oven $\left(100^{\circ} \mathrm{C}\right.$ for 24 hr). The weight of solubilized dry matter was calculated by subtracting the weight of unsolubilized dry matter from the initial weight of dry matter and reported on an initial dry weight basis.

\section{Protein Solubility}

Small pieces of films $(\approx 1 \mathrm{~g})$ were placed in a desiccator over calcium sulfate $(0 \% \mathrm{rh})$ for $72 \mathrm{hr}$. Dried film samples $(10-20 \mathrm{mg})$ were accurately weighed and placed into test tubes, to which $5 \mathrm{~mL}$ of distilled water were added. Test tubes were covered with wrapping film (Parafilm M, American National Can, Greenwich, CT) and incubated at room temperature for $24 \mathrm{hr}$. Tubes were gently shaken and $1 \mathrm{~mL}$ of the solution was put into microfuge tubes and centrifuged at 2,000 rpm for $10 \mathrm{~min}$. A $100-\mu \mathrm{L}$ sample of the supernatant was analyzed for protein content with the bicinchoninic acid (BCA) protein assay kit (Sigma procedure no. TPRO-562, Sigma Chemical Co., St. Louis, MO) using bovine serum albumin as the standard for protein quantitation (Smith et al 1985). Protein solubility (PS) results were reported as the percentage of total protein detected in solution. The initial amount of protein in the dry films was calculated from the initial dry film weight after accounting for both the protein to glycerol ratio in the film and the protein content of the LSI, CSI, 7S, or 11S powder.

\section{Water Vapor Permeability}

Water vapor permeability (WVP) of films was determined gravimetrically using methodology similar to that described by Gennadios et al (1994b). Cups with an open mouth area of $16.6 \mathrm{~cm}^{2}$ were filled with $15 \mathrm{~mL}$ of distilled water, and film specimens $(7 \times$ $7 \mathrm{~cm}$ ) were tightly sealed on the cups by means of a lid, four screws, and a rubber O-ring. The cup assemblies were weighed and placed in an environmental chamber at $50 \%$ rh and $25^{\circ} \mathrm{C}$. Air circulation inside the chamber was provided by a fan $(198 \mathrm{~m} / \mathrm{min}$ air speed). Moisture loss was monitored by weighing the cups at 1-hr intervals during an 8-hr period. Steady state was reached within $2 \mathrm{hr}$. Linear regression-derived slopes of the steady state (linear) portion of weight loss versus time curves were used to estimate water vapor transmission rate (WVTR) in $\mathrm{g} / \mathrm{m}^{2} \times \mathrm{hr}$. WVP $\left(\mathrm{g} \times \mathrm{mm} / \mathrm{m}^{2} \times \mathrm{hr} \times \mathrm{kPa}\right)$ was calculated as: WVP $=$ $\operatorname{WVTR}(L / \Delta P)$, where $L$ was film thickness $(\mathrm{mm})$ and $\Delta P$ was partial water vapor pressure difference between the two sides of the film $(\mathrm{kPa})$.

\section{Color Measurement}

Color values of soy protein films were measured with a chroma meter (CR-300, Minolta Camera Co., Osaka, Japan). Film specimens were placed on the surface of a white standard plate (calibration plate CR-A43) and Hunter $L, a$, and $b$ color values were measured. The three color coordinates ranges were: $L$ ( 0 black to 100 white), $a$ (-greenness to + redness), and $b$ (-blueness 
to + yellowness) (Francis and Clydesdale 1975). Total color difference $(\Delta E)$ was calculated as:

$$
\Delta E=\left[\left(L_{\text {film }}-L_{\text {standard }}\right)^{2}+\left(a_{\text {film }}-a_{\text {standard }}\right)^{2}+\left(b_{\text {film }}-b_{\text {standard }}\right)^{2}\right]^{0.5}
$$

Standard values refer to the white calibration plate $(L=96.86, a$ $=-0.02$, and $b=1.99)$.

\section{Statistical Analysis}

Measurements of each property were replicated three times for each type of film, with individually prepared and cast films as the replicated experimental units. Each property replicate was the mean of two tested sampling units taken from the same film. Statistics on a completely randomized design were determined using the General Linear Models procedure in the SAS program (SAS $1988)$. Mean property values were separated $(P<0.05)$ with Duncan's multiple range test (Steel and Torrie 1980).

\section{RESULTS AND DISCUSSION}

\section{Gel Electrophoresis}

SDS-PAGE gels prepared in this study are shown in Figure 1. Both laboratory-prepared 7S and 11S fractions had relatively high purity. The level of cross-contamination between the two fractions was typical for the isolation technique used (Thanh and Shibasaki 1976, Winters et al 1990). Similar electrophoretic patterns of protein subunits were obtained for CSI and LSI.

\section{Tensile Strength and Elongation}

Mean TS and E values for 7S, 11S, CSI, and LSI films are presented in Table I. Films made from $11 \mathrm{~S}$ soy globulin fraction had significantly $(P<0.05)$ greater TS, by $\approx 46 \%$, than did films from $7 \mathrm{~S}$. Similarly, it has been previously reported that yuba-like films (formed on the surface of heated soy protein solutions) from $11 \mathrm{~S}$ were stronger than films from 7S (Shirai et al 1974, Okamoto, 1978). Covalent disulfide bonds are believed to play a major role in soy protein film formation (Gennadios and Weller 1991). Therefore, the higher tendency of $11 \mathrm{~S}$ protein to form disulfide bonds than 7S protein (Saio et al 1971) could be responsible for $11 \mathrm{~S}$ films being stronger. LSI films had greater $(P<0.05)$ TS than did CSI films (Table I). This was attributed to LSI powder having a higher protein content $(94.4 \%$, db) than CSI powder $(91.5 \%$,

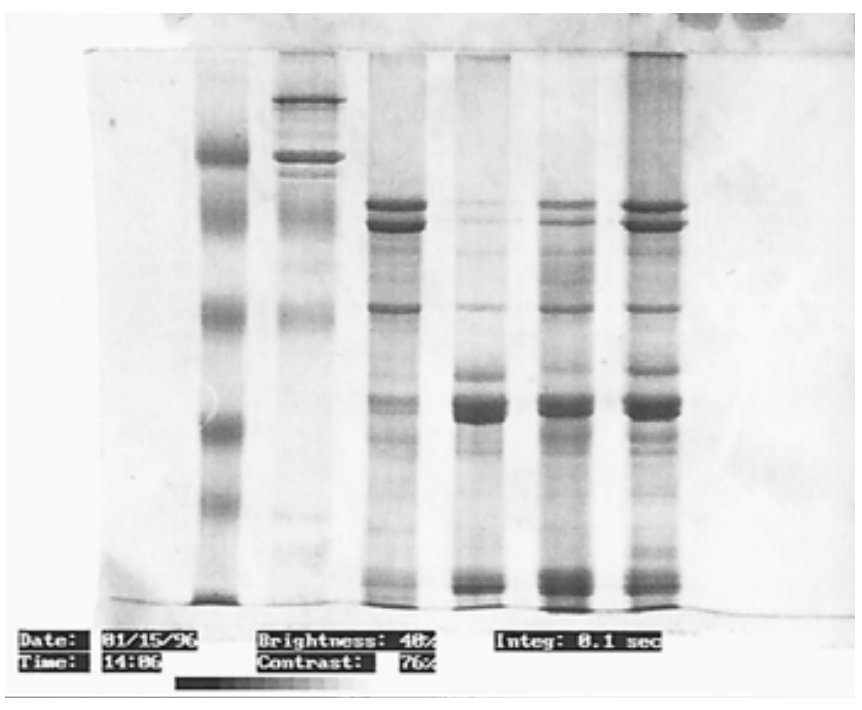

Fig. 1. Sodium dodecyl sulfate polyacrylamide gel electrophoresis patterns for laboratory-prepared 7S soy protein fraction (lane 3 from left); laboratory-prepared 11S soy protein fraction (lane 4); laboratoryprepared soy protein isolate (lane 5); and commercial soy protein isolate (lane 6). $\mathrm{db}$ ), since nonprotein constituents are likely to disrupt the homogeneity and continuity of the protein film network. In agreement with this, Wall and Beckwith (1969) showed that commercial wheat gluten did not yield as strong a film as laboratory-prepared wheat gluten. Also, Gennadios and Weller (1992) reported that films prepared from a $75 \%(\mathrm{db})$ protein content commercial wheat gluten had lower TS than that of films prepared from an $82 \%(\mathrm{db})$ protein content commercial wheat gluten.

In contrast to $\mathrm{TS}$, no significant $(P>0.05)$ differences were detected among mean $\mathrm{E}$ values of $7 \mathrm{~S}, 11 \mathrm{~S}$, CSI, and LSI films (Table I). It should be noted that film thickness was not accounted for in calculation of $\mathrm{E}$ values as was the case with calculation of TS values. Therefore, the substantial variability in measured $E$ values and failure to detect differences among mean values may have been due to the small thickness variations of tensile testing film specimens.

\section{Solubility in Water}

Stuchell and Krochta (1994) reported that pieces of glycerolplasticized films from commercial soy protein isolate maintained their integrity after incubation in water for $24 \mathrm{hr}$ with occasional gentle agitation. They suggested that only monomers, small peptides, and nonprotein materials solubilized in water. Film pieces immersed in water in the present study were not broken apart and the film network remained intact. Most likely, the hydrophilic glycerol constituted a large part of the film TSM.

TABLE I

Tensile Strength (TS), Percent Elongation at Break (E), Protein Solubility (PS), and Total Soluble Matter (TSM) of Soy Protein Films ${ }^{\mathrm{a}}$

\begin{tabular}{lrrcc}
\hline Film & \multicolumn{1}{c}{ TS (MPa) } & E $(\%)$ & PS $(\%)$ & TSM $(\%)$ \\
\hline 7S & $7.36 \pm 0.42 \mathrm{a}$ & $37.06 \pm 18.5 \mathrm{a}$ & $8.59 \pm 0.20 \mathrm{c}$ & $39.41 \pm 1.56 \mathrm{~d}$ \\
$11 \mathrm{~S}$ & $10.77 \pm 0.63 \mathrm{~b}$ & $37.93 \pm 18.5 \mathrm{a}$ & $3.99 \pm 0.05 \mathrm{a}$ & $26.81 \pm 0.16 \mathrm{a}$ \\
CSI $^{\mathrm{b}}$ & $8.53 \pm 0.48 \mathrm{a}$ & $31.93 \pm 2.4 \mathrm{a}$ & $6.51 \pm 0.26 \mathrm{~b}$ & $35.11 \pm 0.99 \mathrm{c}$ \\
LSI $^{\mathrm{c}}$ & $10.68 \pm 0.95 \mathrm{~b}$ & $41.66 \pm 22.0 \mathrm{a}$ & $12.19 \pm 0.30 \mathrm{~d}$ & $29.91 \pm 1.95 \mathrm{~b}$ \\
\hline
\end{tabular}

${ }^{a}$ Means of three replicates \pm a standard deviation. Any two means in the same column followed by the same letter are not significantly $(P>0.05)$ different according to Duncan's multiple range test.

b Commercial soy protein isolate.

${ }^{c}$ Laboratory-prepared soy protein isolate.

TABLE II

Water Vapor Permeability (WVP) a foy Protein Films at $25^{\circ} \mathrm{C}$

\begin{tabular}{lccc}
\hline Film & Thickness $(\mu \mathbf{m})$ & $\mathbf{W V P}\left(\mathbf{g} \times \mathbf{~ m m} / \mathbf{m}^{2} \times \mathbf{h r} \times \mathbf{k P a}\right)$ & $\mathbf{r h}^{\mathbf{b}} \mathbf{( \% )}$ \\
\hline $7 \mathrm{~S}$ & $65 \pm 4.5$ & $4.39 \pm 0.59$ & $73.14 \pm 0.76$ \\
$11 \mathrm{~S}$ & $57 \pm 7.0$ & $4.27 \pm 0.54$ & $71.82 \pm 0.16$ \\
$\mathrm{CSI}^{\mathrm{c}}$ & $54 \pm 6.0$ & $3.76 \pm 0.16$ & $73.26 \pm 1.20$ \\
LSI $^{\mathrm{d}}$ & $62 \pm 6.1$ & $3.88 \pm 0.30$ & $74.00 \pm 0.53$ \\
\hline
\end{tabular}

${ }^{a}$ Means of three replicates \pm a standard deviation. No significant $(P>0.05)$ differences were detected among WVP means.

b Actual rh values at the underside of films calculated as described by Gennadios et al (1994b) to account for resistance of stagnant air layer between film and water surface in testing cups. rh outside the cups was $50 \%$.

${ }^{c}$ Commercial soy protein isolate.

${ }^{\mathrm{d}}$ Laboratory-prepared soy protein isolate.

TABLE III

Hunter Color Values $(L, a$, and $b)$ and Total Color Differences $(\Delta E)$ of Soy Protein Films ${ }^{\mathrm{a}}$

\begin{tabular}{lcccc}
\hline Film & $\boldsymbol{L}$ & $\boldsymbol{a}$ & $\boldsymbol{b}$ & $\Delta \boldsymbol{E}$ \\
\hline $7 \mathrm{~S}$ & $94.25 \pm 0.35 \mathrm{a}$ & $-2.42 \pm 0.25 \mathrm{a}$ & $11.64 \pm 1.05 \mathrm{ab}$ & $10.28 \pm 1.12 \mathrm{ab}$ \\
$11 \mathrm{~S}$ & $94.83 \pm 0.44 \mathrm{a}$ & $-3.16 \pm 0.16 \mathrm{~b}$ & $10.66 \pm 0.70 \mathrm{~b}$ & $9.55 \pm 0.68 \mathrm{~b}$ \\
CSI $^{\mathrm{b}}$ & $93.05 \pm 0.40 \mathrm{~b}$ & $-2.46 \pm 0.34 \mathrm{a}$ & $12.62 \pm 1.43 \mathrm{a}$ & $11.56 \pm 1.50 \mathrm{a}$ \\
LSI $^{\mathrm{c}}$ & $94.77 \pm 0.16 \mathrm{a}$ & $-2.30 \pm 0.18 \mathrm{a}$ & $9.93 \pm 0.87 \mathrm{~b}$ & $8.53 \pm 0.79 \mathrm{~b}$ \\
\hline
\end{tabular}

a Film color was measured by placing films on top of a standard white plate $(L=96.86, a=-0.02$, and $b=1.99)$. Presented values are means of three replicates \pm a standard deviation. Any two means in the same column followed by the same letter are not significantly $(P>0.05)$ different according to Duncan's multiple range test.

${ }^{b}$ Commercial soy protein isolate.

${ }^{c}$ Laboratory-prepared soy protein isolate. 
Films from 7S had higher $(P<0.05)$ TSM and PS values than $11 \mathrm{~S}$ films (Table I). This was attributed to the lower molecular weight of $7 \mathrm{~S}$ proteins, the higher tendency of $11 \mathrm{~S}$ proteins to form disulfide bonds (Saio et al 1971), which stabilize the film network, and the more lipophilic nature of $11 \mathrm{~S}$ proteins (Watanabe et al 1975). The higher $(P<0.05)$ TSM of CSI films compared to LSI films (Table I) was likely due to the presence of a greater amount of nonprotein impurities in the CSI powder. However, CSI films had lower $(P<0.05)$ PS than did LSI films.

\section{Water Vapor Permeability}

No significant $(P>0.05)$ differences were detected among WVP values of 7S, 11S, CSI, and LSI films (Table II). In general, protein films are poor water vapor barriers due to the inherent high hydrophilicity of proteins and the substantial amount of hydrophilic plasticizers added to protein films (Gennadios et al 1994a). For the sake of comparison, low density polyethylene films have WVP values ( $25 \mu \mathrm{m}$ films, $90 \%$ rh gradient, $38^{\circ} \mathrm{C}$ ) ranging from 0.0026 to $0.0035 \mathrm{~g} \times \mathrm{mm} / \mathrm{m}^{2} \times \mathrm{hr} \times \mathrm{kPa}$ (Briston 1988), which are lower by three orders of magnitude than WVP values of soy protein films measured in the present study.

\section{Film Color}

Color is an important property of protein films because it could affect consumer acceptance of such films in potential edible or nonedible packaging applications. Hunter $L, a$, and $b$ color values and total color differences for 7S, 11S, CSI, and LSI films are shown in Table III. CSI films were slightly but significantly $(P<0.05)$ darker (lower mean $L$ value) and more yellow (greater mean positive $b$ value) than the other three types of films. This was attributed to the greater amount of impurities present in the CSI powder.

\section{Implications and Potential Applications}

This study showed that soy protein isolate of increased purity can yield stronger films than commercially available soy protein isolate. Also, use of $11 \mathrm{~S}$ soy globulin fraction alone can give stronger films than commercial soy protein isolate. However, this improvement in film strength would come at the additional costs of further purifying soy protein isolate or separating the $11 \mathrm{~S}$ protein fraction. Although soy protein films are poor water vapor barriers, they have been found to be very effective oxygen barriers (Brandenburg et al 1993, Gennadios et al 1993b). The good oxygen barrier ability of soy protein films could be utilized in the manufacture of multilayer packagings where soy protein films would function as the oxygen barrier-providing layer. In another potential application, soy protein coatings on precooked meat products could control lipid oxidation and limit surface moisture loss. Incorporation of antioxidants and flavoring agents in soy protein coatings could improve overall quality characteristics of food products. The high hydrophilicity and substantial solubility of soy protein films in water could possibly render such films appropriate for manufacture of hot water soluble pouches, similar to the cellulose ether-based water soluble pouches which are currently in commercial use.

\section{ACKNOWLEDGMENT}

This research was partially funded by the Nebraska Soybean Development, Utilization, and Marketing Board.

\section{LITERATURE CITED}

AOAC. 1990. Official Methods of Analysis of the Association of Official Analytical Chemists. 15th ed. Method 981-10. The Association: Washington, DC.

BRISTON, J. H. 1988. Plastic Films. 3rd ed. Longman Scientific \& Technical: Essex, England.

BRANDENBURG, A. H., WELLER, C. L., and TESTIN, R. F. 1993. Edible films and coatings from soy protein. J. Food Sci. 58:1086-1089.
FRANCIS, F. J., and CLYDESDALE, F. M. 1975. Food Colorimetry. Theory and Applications. AVI: Westport, CT.

GENNADIOS, A., and WELLER, C. L. 1991. Edible films and coatings from soymilk and soy protein. Cereal Foods World 36:1004-1009.

GENNADIOS, A., and WELLER, C. L. 1992. Tensile strength increase of wheat gluten films. ASAE Paper No. 92-6517. Am. Soc. Agric. Eng.: St. Joseph, MI.

GENNADIOS, A., BRANDENBURG, A. H., WELLER, C. L., and TESTIN, R. F. 1993a. Effect of pH on properties of wheat gluten and soy protein isolate films. J. Agric. Food Chem. 41:1835-1839.

GENNADIOS, A., WELLER, C. L., and TESTIN, R. F. 1993b. Temperature effect on oxygen permeability of edible protein-based films. J. Food Sci. 58:212-214, 219.

GENNADIOS, A., McHUGH, T. H., WELLER, C. L., and KROCHTA, J. M. 1994a. Edible coatings and films based on proteins. Pages 201277 in: Edible Coatings and Films to Improve Food Quality. J. M. Krochta, E. A. Baldwin, and M. O. Nisperos-Carriedo, eds. Technomic: Lancaster, PA.

GENNADIOS, A., WELLER, C. L., and GOODING, C. H. 1994b. Measurement errors in water vapor permeability of highly permeable, hydrophilic edible films. J. Food Eng. 21:395-409.

GONTARD, N., GUILBERT, S., and CUQ, J.-L. 1992. Edible wheat gluten films: Influence of the main process variables on film properties using response surface methodology. J. Food Sci. 57:190-195, 199.

HAMES, B. D., and RICKWOOD, D. 1981. Gel Electrophoresis of Proteins-A Practical Approach. IRL Press: Oxford, England.

IWABUCHI, S., and YAMAUCHI, F. 1987. Electrophoretic analysis of whey proteins present in soybean globulin fractions. J. Agric. Food Chem. 35:205-209.

JAYNES, H. O., and CHOU, W. N. 1975. New methods to produce soy protein-lipid films. Food Prod. Dev. 9(4):86-90.

KESTER, J. J., and FENNEMA, O. R. 1986. Edible films and coatingsA review. Food Technol. 40(12):47-59.

NAKAMURA, T., UTSUMI, S., and MORI, T. 1985. Effects of temperature on the different stages of thermal gelling of glycinin. J. Agric. Food Chem. 33:1201-1203.

OKAMOTO, S. 1978. Factors affecting protein film formation. Cereal Foods World 23:256-262.

ROMIJN, A., CUPPETT, S. L., ZEECE, M. G., PARKHURST, A. M., and LEE, M. L. 1991. Impact of soy protein isolates and specific fractions on rancidity development in cooked, refrigerated beef system. J. Food Sci. 56:188-190.

SAIO, K., KAJIKAWA, M., and WATANABE, T. 1971. Food processing characteristics of soybean proteins. II. Effect of sulphydryl groups on physical properties of tofu-gel. Agric. Biol. Chem. 35:890-898.

SAS. 1988. SAS/STAT User's Guide. Release 6.03. The Institute: Cary, NC.

SHIRAI, M., WATANABE, K., and OKAMOTO, S. 1974. Contribution of $11 \mathrm{~S}$ and $7 \mathrm{~S}$ globulins of soybean protein to the formation and properties of yuba-film. Nippon Shokuhin Kogyo Gakkaishi 21:324-328.

SMITH, P. K., KROHN, R. I., HERMANSON, G. T., MALLIA, A. K., GARTNER, F. H., PROVENZANO, M. D., FUJIMOTO, E. K., GOEKE, N. M., OLSON, B. J., and KLENK, D. C. 1985. Measurement of protein using bicinchoninic acid. Anal. Biochem. 150:76-85.

STEEL, R. G. D., and TORRIE, J. H. 1980. Principles and Procedures of Statistics. A Biometrical Approach. 2nd ed. McGraw-Hill: New York.

STUCHELL, Y. M., and KROCHTA, J. M. 1994. Enzymatic treatments and thermal effects on edible soy protein films. J. Food Sci. 59:13321337.

THANH, V. M., and SHIBASAKI, K. 1976. Major proteins of soybean seeds. A straightforward fractionation and their characterization. J. Agric. Food Chem. 24:1117-1121.

WALL, J. S., and BECKWITH, A. C. 1969. Relationship between structure and rheological properties of gluten proteins. Cereal Sci. Today 14:16-18, 20-21.

WANG, H. L. 1981. Oriental soybean foods. Food Dev. 15(5):29-34.

WATANABE, K., WATANABE, T., and OKAMOTO, S. 1975. On the contribution of lipids to the properties of yuba film. Nippon Shokuhin Kogyo Gakkaishi 22:143-147.

WINTERS, D. D., CUPPETT, S. L., and ZEECE, M. G. 1990. Comparison of purification procedures for $\beta$-conglycinin and effect of toasting. J. Food Sci. 55:283-284. 